\title{
Inequality in homeschooling during the Corona crisis in the Netherlands. First results from the LISS Panel.
}

\author{
Thijs Bol* \\ University of Amsterdam, t.bol@uva.nl \\ Working Paper, April 30, 2020
}

\begin{abstract}
The outbreak of the Corona virus has led to unprecedented measures in education. From March 16, all schools in the Netherlands are closed, and children must keep up with their schoolwork from home. Parents are expected to take a crucial role in this "homeschooling": they are primarily responsible for ensuring that their children follow the curriculum. In this article I report the first results of a module in the LISS Panel that was designed to map how parents school their children in primary and secondary education. Data on a nationally representative sample of 1,318 children in primary and secondary education were gathered in April. The results show marked differences between social groups. Whereas all parents find it important that their children keep up with the schoolwork, children from advantaged backgrounds receive much more parental support and have more resources (e.g., own computer) to study from home. Differences in parental support are driven by the ability to help: parents with a higher education degree feels themselves much capable to help their children with schoolwork than lower educated parents. Parents also report that schools provide more extensive distant schooling for children in the academic track in secondary education (vwo) than for children in the pre-vocational track vmbo. Finally, there is a clear gender gap: parents feel much more capable to support their daughters than their sons. These initial findings provide first indications that the school shutdown in the Netherlands is likely to have strong effects on the inequality in educational opportunities.
\end{abstract}

*The research in this article has been supported by an ODISSEI grant to collect data during the Covid-19 crisis. I would like to thank Joost Leenen for his help with programming the survey and Sara Geven and Dieuwke Zwier for their comments on the initial version of the survey. 


\section{Introduction}

The Covid-19 pandemic has led to unprecedented measures in education. From March 16, all schools in the Netherlands are closed, and children must keep up with their schoolwork from home. Parents are expected to take a crucial role in this "homeschooling": they are primarily responsible for ensuring that their children follow the curriculum. Within the LISS panel I have gathered data to investigate how parents (differently) deal with homeschooling. A worry is that the long period of exposure to homeschooling is likely to increase socioeconomic inequalities in education, as children from disadvantaged families have less resources to study and less access to help when studying from home. To what extent do children from different socio-economic backgrounds get the same opportunities to learn during the school shutdown?

A key finding in sociology, educational sciences, and economics is that children from disadvantaged families have fewer opportunities in education than children from a higher socio-economic background (Breen and Jonsson, 2005) In the Netherlands these inequalities are reported too: the Dutch Educational Inspectorate repeatedly reported large gaps in educational outcomes between children of higher and lower educated parents (Inspectie van het Onderwijs, 2017). One of the key reasons why children that grow up in advantaged families have better opportunities is because they have more resources to learn (Bourdieu, 1973). Partly these resources are material, but partly these resources are immaterial and closely related to parental involvement in schooling.

First, some families lack important educational resources (e.g., computers, software) that are required for doing schoolwork. This problem of a lack of material resources might be even more urgent in a situation where all school-going children are at home, and one computer within the family might not be sufficient. There might also be variation in the living space per household member, which might impede the possibility for quiet study. This lack of material resources that can be crucial for doing schoolwork from home are clustered in disadvantaged families, where income is low (Angus et al., 2004). Another resource that might be scarcer among some families is time. Some children grow up in a household with two caretakers, others with just one. There is a clear socio-economic gradient in the time that parents can spend with their children

Second, parental involvement in schoolwork is known to have a strong effect on educational outcomes. When parents are more involved with schoolwork, cognitive test scores are found to be higher, resulting in higher levels of educational attainment (Boonk et al., 2018). Similar results are found for the Netherlands (Driessen et al., 2005). ${ }^{1}$

Socio-economic gaps in parental involvement are likely to increase existing inequalities in education too. Lower-educated parents are, on average, less capable

\footnotetext{
${ }^{1}$ It is important to take into account that parental involvement is partly driven by the demand: meaning that lower performing children will receive more support because they need it (see also (Driessen et al., 2005)). However, this does not explain socio-economic gaps in parental involvement.
} 
to provide adequate help in their children's schooling (Lee and Bowen, 2006). Higher educated parents, in contrast, try to foster and enhance their children's talents by offering them ample opportunities to learn (Lareau, 2011). They are very aware of the importance of education to get ahead in society, and actively try to advance their children's schooling careers (Calarco, 2018; Lareau, 2011). When it comes to help with schoolwork, higher-educated parents are both more able to help out, but also believe that more help is needed. Both mechanisms will increase existing inequalities in education.

In a normal situation, this strong variation in opportunities that children get at home is at least partly mitigated by school: everyone can learn during school times. Schools are thereby thought to be highly important for creating equal opportunities in society. However, because of the Covid-19 outbreak schools are closed, and parents have become primarily responsible for the learning of their children. Given the strong socio-economic gradient that is found in resources at home, this is likely to increase socio-economic gaps in education. During the school shutdown, children from different backgrounds get widely different opportunities to learn.

In the Netherlands the full school shutdown will last for 8 weeks for children in primary school. After this, children will return to primary schools for half of the time; the remaining schoolwork is expected to be done at home. Secondary schools in the Netherlands will remain closed, with the intention to (partially) re-open them on June 1, 2020. While this period might seem like a short period, existing research finds that even short breaks are likely to increase inequalities. Alexander et al. (2001) show that in the United States socio-economic inequalities increase during the 2-3 month summer break. Children from advantaged backgrounds get ample opportunities to develop, whereas this is not the case for children from disadvantaged families. This "summer setback" is has lasting effects on educational performance in, for example, mathematics (Alexander et al., 2007).

The school shutdown driven by the Covid-19 pandemic has a large impact on how children learn. In order to map this, I have surveyed a representative sample of Dutch parents about their school-going children using the LISS-Panel. The goal of the data collection is twofold. First, to describe (social inequalities in) how parents support their children with schooling during the school shutdown. Second, to track the short- and long-term consequences of (social inequality) in homeschooling. In this brief article I will describe preliminary results regarding the first question.

\section{Data}

Data for the survey were collected from April 13 to April 28 within the LISS (Longitudinal Internet Studies for the Social sciences) Panel. The LISS panel consists of 4,500 households, containing about 7,000 individuals. LISS collects data using online questionnaires. The panel consists of households from a true probability sample of households drawn from the Dutch population registers by 
Statistics Netherlands. Whenever a household wanted to participate but was not able because they lacked a computer or internet connection, LISS provided them with it. Every month, members of the LISS Panel complete online questionnaires of about 15 to 30 minutes in total. Panel members are remunerated for each completed questionnaire. A longitudinal survey is fielded in the panel every year, covering a large variety of domains including work, education, income, housing, time use, political views, values and personality. In addition to this LISS Core Study, many separate modules are fielded to collect scientific data for scholars from widely different disciplines, from sociology to medical sciences.

\subsection{Sample}

For the current LISS module on homeschooling during the school shutdown, only panel members with children in the school-going ages for primary and secondary education (4-18 years old) were targeted. If two caretakers ${ }^{2}$ were living in the same household, both had the opportunity to fill in the survey. In total 1,212 panel members met the criteria, 898 filled in the questionnaire, which means a response rate of $74 \%$. The final analytic sample contains information from 768 parents: 130 parents did have children in the school going age, but these children were not enrolled in secondary school anymore (but in an upper secondary vocational course $m b o$ or tertiary vocational education $h b o$ ). The LISS Panel does not provide weights, which means that selective non-response cannot be accounted for.

All parents were asked to provide information on all of their children. The final sample therefore contains information on 1,318 children: 705 in primary school, 613 in secondary school. Data are analyzed on the level of the child, meaning that the final sample size of the data is the total number of children.

\subsection{Variables}

The module addressed different themes. First, parents asked about what schools provided them to continue schoolwork at home. Eight items were included, asking parents to rank whether, for example, schools provided them with sufficient information to start homeschooling, or whether children and parents have regular contact with the teacher. All items were measured on a five point Likert-scale.

A second block of items asks parents about how they support their children with their schoolwork. This contains, for example, items on whether parents provide help, whether children organize their own schoolwork, whether there is a clear structure when working on school at home. It also asks parents to indicate the extent of help they believe their child requires, and whether they feel capable to provide this support. Again respondents could score all statements from 1 (Does not apply at all) to 5 (Applies completely). The module also asks parents how much time their children spend on their schoolwork in hours.

\footnotetext{
${ }^{2}$ This can also be one biological parent and one step-parent.
} 
A third block of questions contains information on the material resources that are available at home. Parents are asked whether children have their own device (computer, tablet) to use for their schoolwork, whether children have their own bedroom, and whether children have a quiet place to study. Finally, parents are asked whether they have bought extra software to aid their children with schoolwork or whether children are now participating in extra (online) tutoring classes. All these items are measured on a binary scale (yes or no).

In the module I also gathered information on the household. First, it tries to map the atmosphere at home. Six items measure whether there are tensions, whether there is a lot of fighting, and whether the day is clearly structured. Second, we measure the perceived poverty of a household using four items, by asking parents whether they can go on multiple holidays every year, or whether there is enough money to undertake fun activities with the family. These four items are transformed in a "perceived poverty"-scale, with an Cronbach's $\alpha$ of .74. An overview of all (Dutch) questions in this LISS Module can be found in the Appendix.

From the LISS Core module we include several other characteristics of panel members (and their partners). Final educational attainment of the parents is measured in four categories: low (primary school, only secondary school (vmbo, havo, vwo)), upper secondary vocational $(m b o)$, tertiary vocational ( $h b o)$, or university $(w o)$. When mapping whether there are socio-economic inequalities in homeschooling, I will mostly rely on the parents' education to describe gaps $^{3}$. LISS also contains information on the language that is primarily spoken at home. This variable is recoded into 0 (Dutch) and 1 (Any language other than Dutch). Although the variable is not available for all parents in the module, we do include it when estimating gaps.

Descriptive statistics of the data for the parents are shown in Table 1 and for the children in Table 2.

Table 1: Descriptives of parents

\begin{tabular}{lrr}
\hline & Mean & SD \\
\hline Education level & & \\
Low & .20 & \\
Mbo & .33 & \\
Hbo & .32 & \\
Wo & .16 & \\
Number of school-going children & 1.72 & .77 \\
Perceived poverty (std.) & 0 & .74 \\
Partner in household & .88 & \\
Speaks Dutch in house & .96 & \\
\hline
\end{tabular}

\footnotetext{
${ }^{3}$ Compared to low educated parents, middle $(m b o)$ and high $(h b o, w o)$ educated parents work much often in crucial occupations, and this might unevenly affect their possibility to support their children with schoolwork. We cannot currently include this information, but if anything, this will increase the predicted gaps.
} 
Table 2: Descriptives of children

\begin{tabular}{lrc}
\hline & Mean & SD \\
\hline Primary School & & \\
Age & 8.86 & 1.77 \\
At home during shutdown & .95 & \\
& & \\
Secondary School & & \\
Age & 15.57 & 2.49 \\
At home during shutdown & .96 & \\
Track & & \\
Praktijkonderwijs & .03 & \\
Vmbo-basis & .06 & \\
Vmbo-kader & .10 & \\
Vmbo-t & .18 & \\
Vmbo/havo & .04 & \\
Havo & .21 & \\
Havo/vwo & .06 & \\
Vwo & .32 & \\
Grade year & 3.07 & 1.47
\end{tabular}

\subsection{Methods}

The main goal of this paper is to summarize the first findings from the data collection. This means that I will rely mostly on simple description. There are, however, two methodological considerations. First, children are the unit of analysis but data was gathered at the parental level. Since children are clustered within parents and households, standard errors on the estimates are calculated taking this into account. Second, in primary education the age of the child has a strong effect on the parental support: older children require more support. Since the Dutch educational system is highly tracked, in secondary education a similar problem occurs as children in the academic track (vwo) require different support than children in the track that leads to upper secondary vocational education $(v m b o)$. For this reason the estimates of the gaps in homeschooling are obtained from simple regression models that control for these factors.

\section{Results}

Below the first main findings are summarized. Please note that this is not an exhaustive overview of all variables that were collected, but a first summary of key findings.

\subsection{Primary education}

\subsubsection{School involvement}

In primary education there is variation in how schools dealt with the school shutdown, but there are very little structural differences across groups. Figure B1 
indicates that most parents answer that they got information from schools after the shutdown. There is a bit more variation in the extent to which teachers contacted students. Even more variation can be found when we look at the extent to which parents perceive the communication of schools to be clear. Finally, there is clear variation in the extent to which teachers check the homework of students in primary school. I do not find stark differences in the extent to which parents with different levels of education report differences between schools-there are some indications that schools have relatively more contact with lower-educated parents, but these differences are small and not significantly different from zero.

Figure 1: Parent involvement (primary education)

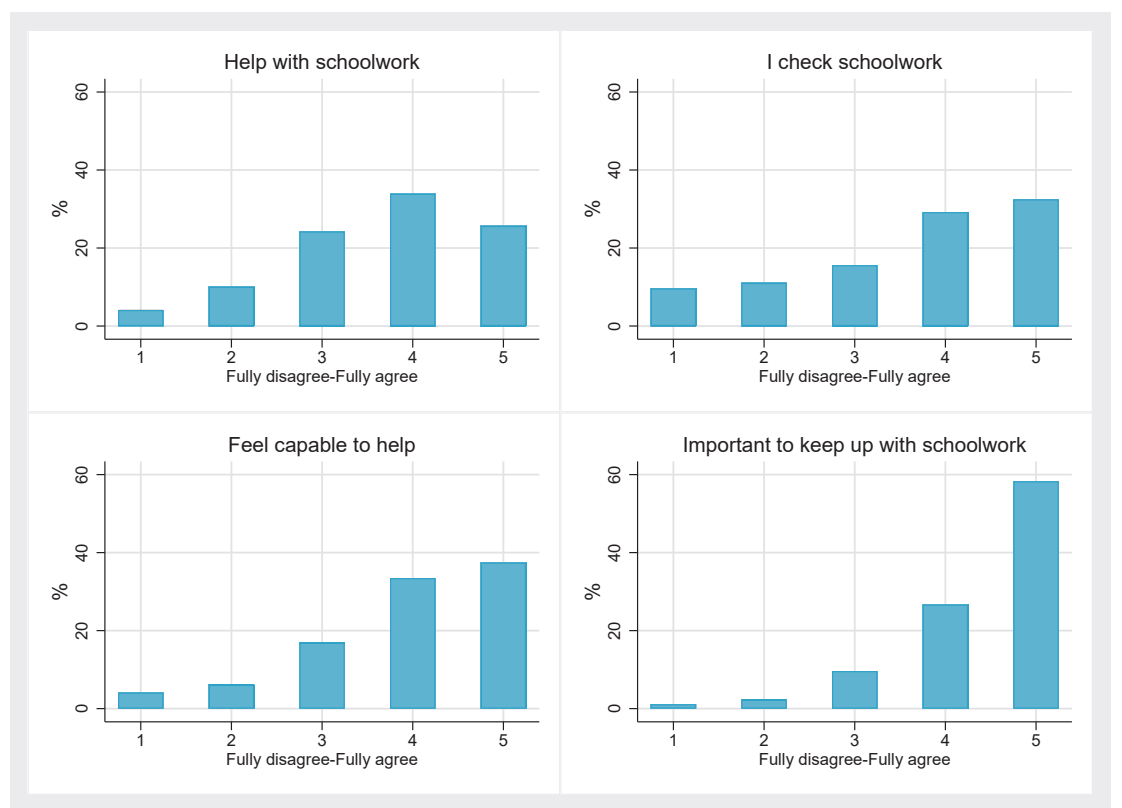

Note. - For the full questions see the Appendix.

\subsubsection{Parental involvement}

Figure 1 shows the distribution of answers to parental involvement. A large share of the parents do not help their children with their schoolwork (upper left panel), but the majority does check whether children have done their schoolwork. Most parents feel capable to help their children in primary school. Almost all parents argue that they find it important that their children keep up with schoolwork during this period.

The differences in parental involvement are partly explained by the educational level of parents. Figure 2 shows the gap between parents with a university degree and parents with a secondary school degree at most. There is a clear educational gradient: higher educated parents are more involved in helping their offspring with their schoolwork and they also feel more capable to do this. These gaps are big, in both cases around $.4 s d$ of the variable. 
Figure 2: Inequality in parental involvement (primary education)

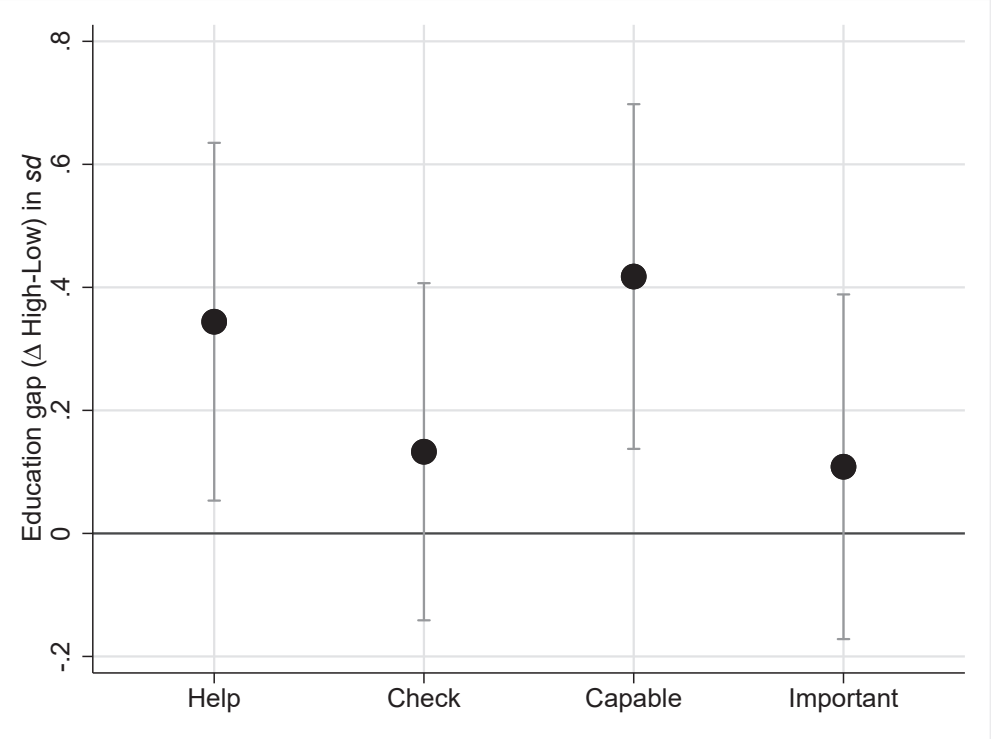

Note. - Predicted gaps based on a regression model, controlling for the age of the child and a binary indicator measuring whether the child worked from home. Whiskers depict $95 \%$ confidence intervals. Standard errors are clustered at the parent and household level.

Phrased differently; about $70 \%$ of the highly educated parents answers that they agree or fully agree with the statement that they help their children with their homework, whereas this is only $50 \%$ of parents with a low level of education. Partly this is driven by the fact that lower educated parents feels less capable to help their primary school children. About $63 \%$ of them feels capable to help their children ${ }^{4}$ compared to $80 \%$ of the university-educated parents. Figure 2 shows that homeschooling during the Covid-19 pandemic is very different for children that grow up with highly educated parents and children that grow up with parents with low education.

\subsubsection{Material resources}

Figure 3 shows how material resources are distributed across children in primary school. The vast majority of children in primary school has their own bedroom (91\%), a smaller share has their own workspace (68\%). About $66 \%$ of children in primary school have a laptop or tablet for their own to do their schoolwork on. This means that about one third does not have their own device, but it should be noted that in primary education having a device is not required by the schools. About $80 \%$ of the parents report that an tablet or computer is necessary to do the schoolwork at home.

While most children have material resources, there is a clear pattern among those who do not have resources. Education does not seem to explain (a lack of) material resources. However, the results do indicate that parents that score high

\footnotetext{
${ }^{4}$ Scoring a 4 or 5 on the 5 point-scale question in Figure 1.
} 
Figure 3: Material resources (primary education)

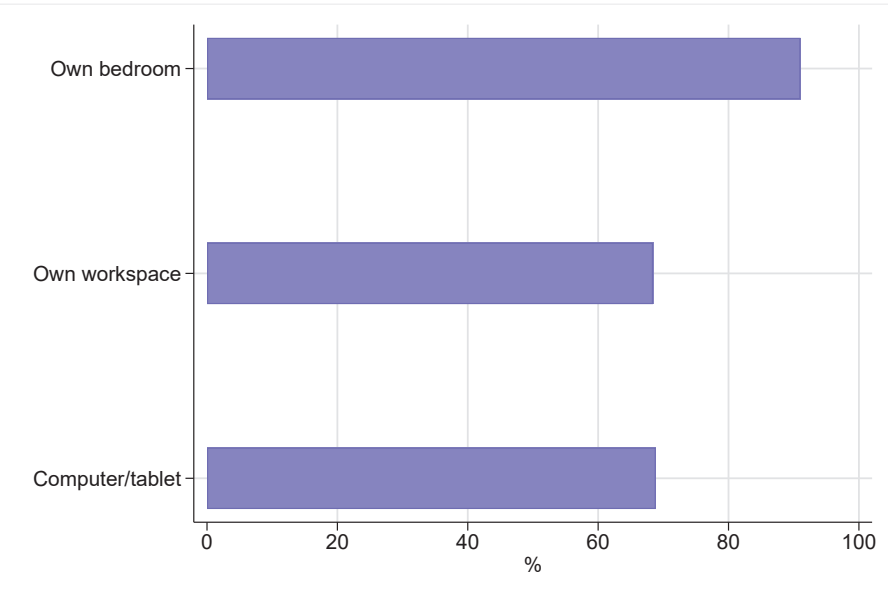

Note. - For the full questions see the Appendix.

on the perceived poverty scale are more likely to lack these material resources.

Figure 4: Material resources and poverty (primary education)

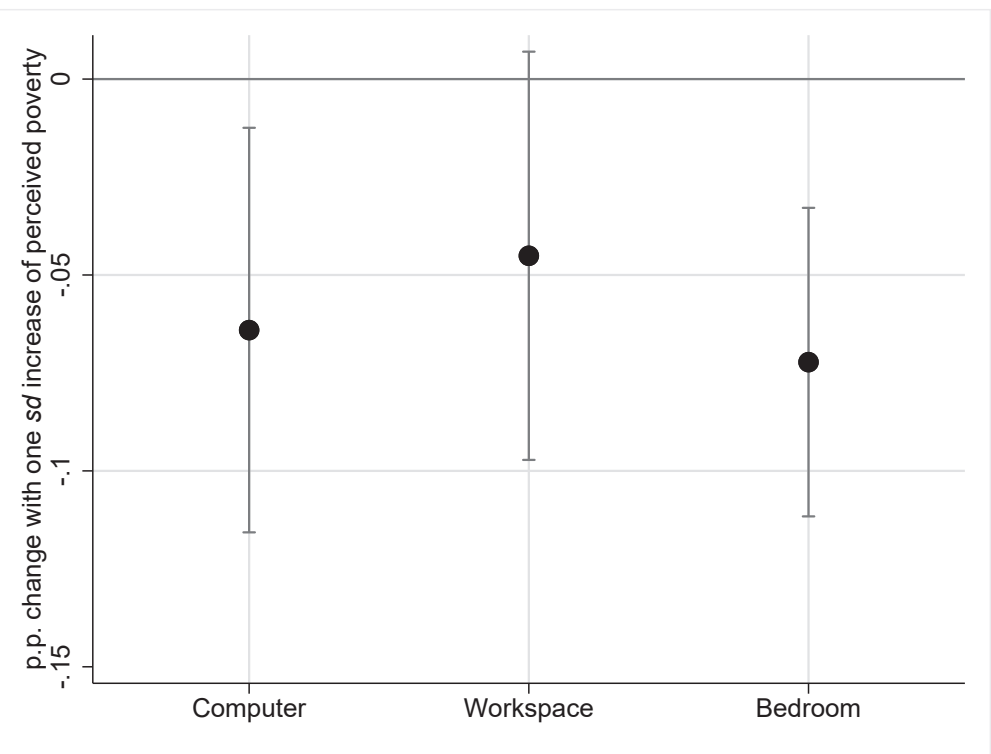

Note. - Predicted gaps based on a regression model, controlling for the age of the child and a binary indicator measuring whether the child worked from home. Whiskers depict $95 \%$ confidence intervals. Standard errors are clustered at the parent and household level.

Figure 4 shows the effect of a $1 s d$ increase on the perceived poverty scale. This effect is about 6 percentage points when it comes to computers, meaning that for each standard deviation increase on the poverty scale children are 6 percentage points less likely to own their own computer or laptop. Similar effect sizes are found for having an own workspace or bedroom, although the effect of workspace does not reach conventional levels of statistical significance. Not 
surprisingly, differences in material resources are explained quite strongly by the income of families. Children that grow up in families at the bottom of the income distribution have least access to resources that can improve learning from home.

\subsection{Secondary education}

\subsubsection{School involvement}

Similar to students in primary education, most parents in secondary education obtained information from the school after the shutdown. Figure 5 also indicates that most students have regular contact with their teachers; about $75 \%$ of the parents agree or fully agree with this statement. There is more variation in the extent to which parents believe the communication was clear (bottom left panel) or whether teachers check the schoolwork of students in secondary education.

Figure 5: School involvement (secondary education)

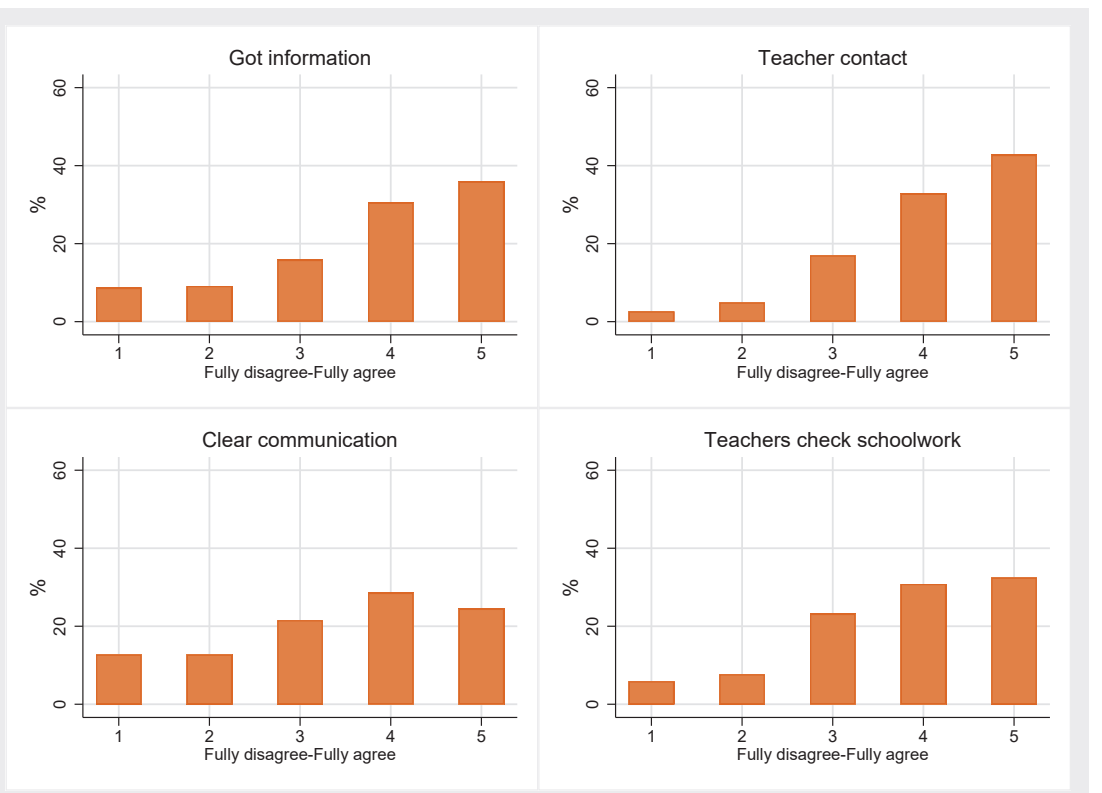

Note. - For the full questions see the Appendix.

These differences vary systematically across children from different backgrounds, but in this case lower educated parents report more involvement of the school. Figure 6 shows the predicted gaps between higher and lower educated parents. This confirms the idea that during the Covid-19 pandemic schools reach out more to students in disadvantaged families, and might also support them more by checking their schoolwork more often. It is clear that in secondary education the extent to which schools are involved in the schoolwork of their pupils is not likely to increase inequality in education.

Large differences in school involvement are found between the educational tracks in Dutch education. Figure 7 shows the gap between what schools offer to students at the vmbo track (the track that leads to upper secondary vocational 
Figure 6: School involvement by parental education (secondary education)

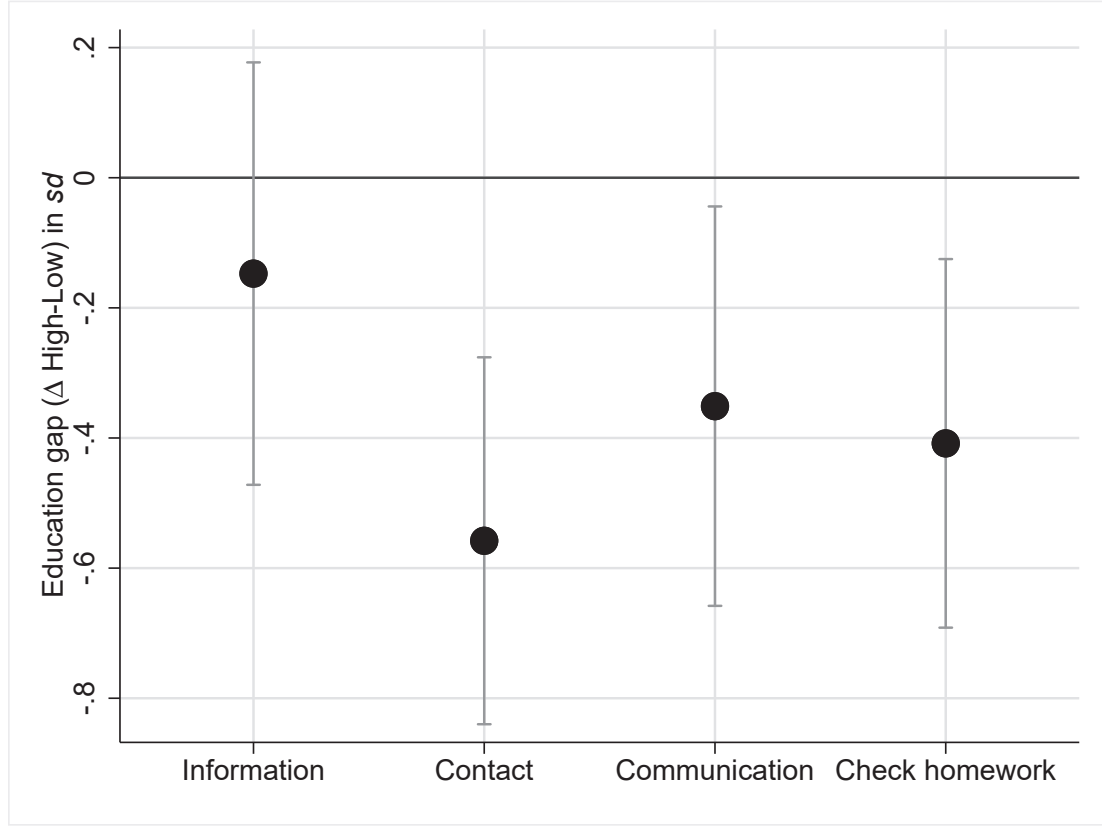

Note. - Predicted gaps based on a regression model, controlling for the age of the child, a binary indicator measuring whether the child worked from home, an indicator for school year, and a dummy for the school track the child is in. Whiskers depict $95 \%$ confidence intervals. Standard errors are clustered at the parent and household level.

education) and the academic vwo track. Parents report that their children in the academic track are much more likely to have had digital classes than children in the pre-vocational track-a gap of almost .5sd. Similarly, children in the academic track much more often receive a structured educational programme, and their schoolwork is checked more often. These findings are not explained by the fact that children in the academic track go to school longer: in the models we control for grade year, basically comparing differences for students in the same grade year.

These gaps clearly indicate that the school shutdown did not only have effects on children from different family backgrounds, but for children in different school tracks too. Parents report that children in the pre-vocational track receive less extensive support from their schools than children in the academic track.

\subsubsection{Parental involvement}

In line with primary school children, there is also variation in the extent to which parents in secondary school support their children with schoolwork. Figure 8 depicts the distribution of four factors of parental involvement. In contrast to primary education, in secondary education parents support their children far less. Moreover, they are less likely to check the schoolwork of the children. There is also more variation in the extent to which parents feel themselves capable to help their children with schoolwork. About $25 \%$ does not feel themselves capable to 
Figure 7: School involvement by educational track

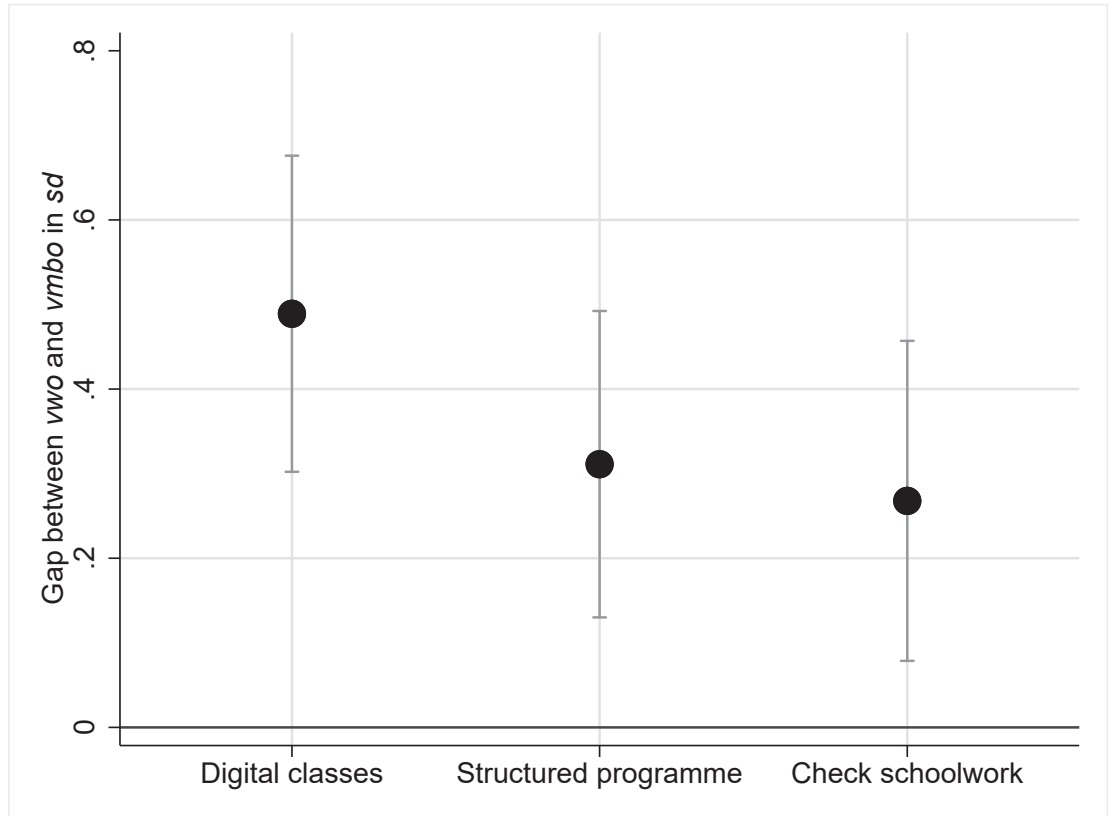

Note. - Predicted gaps based on a regression model, controlling for the age of the child, a binary indicator measuring whether the child worked from home, and an indicator for school year. Whiskers depict 95\% confidence intervals. Standard errors are clustered at parent and household level.

help their children with the schoolwork in secondary education.

Figure 8: Parent involvement in secondary education
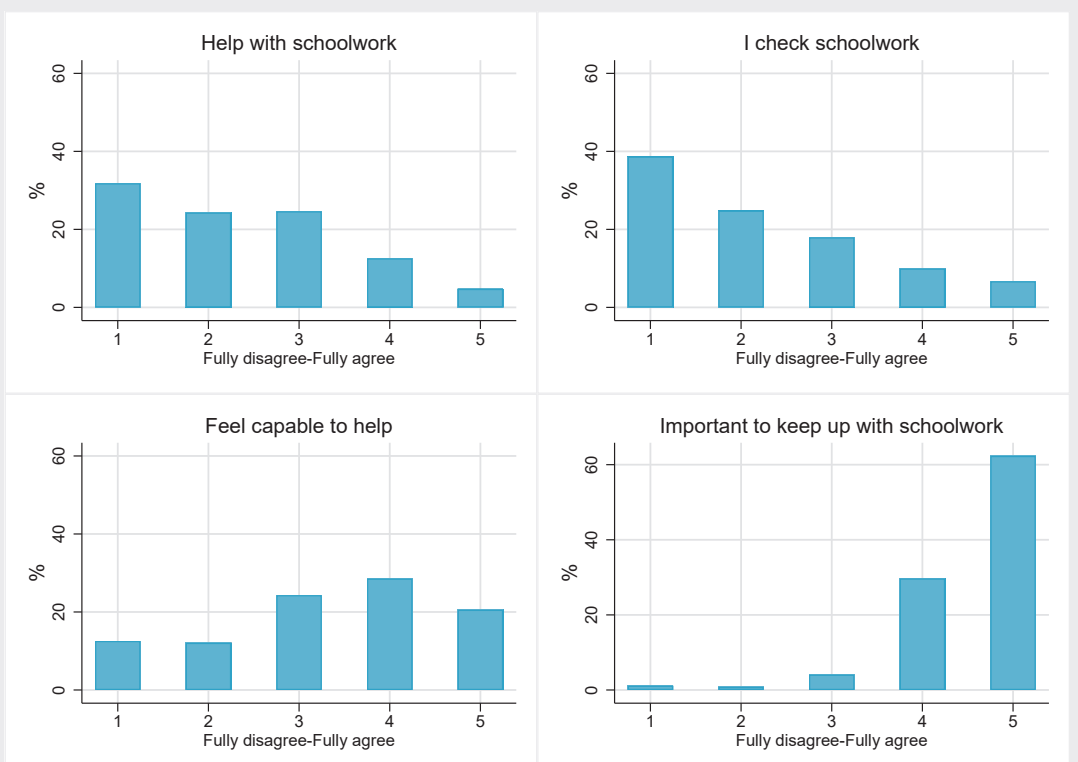

Note. - For the full questions see the Appendix. 
These differences are to a large extent explained by family background. Similar to the findings for primary education, in secondary education highly educated parents support their children more. Figure 9 shows that the differences are substantial. Between the highest and lowest educated parents we find a gap of $.5 \mathrm{sd}$ in the extent to which they support their children in secondary school. This effect is estimated net of the educational track or school year the student is in.

Figure 9: Inequality in parental involvement (secondary education)

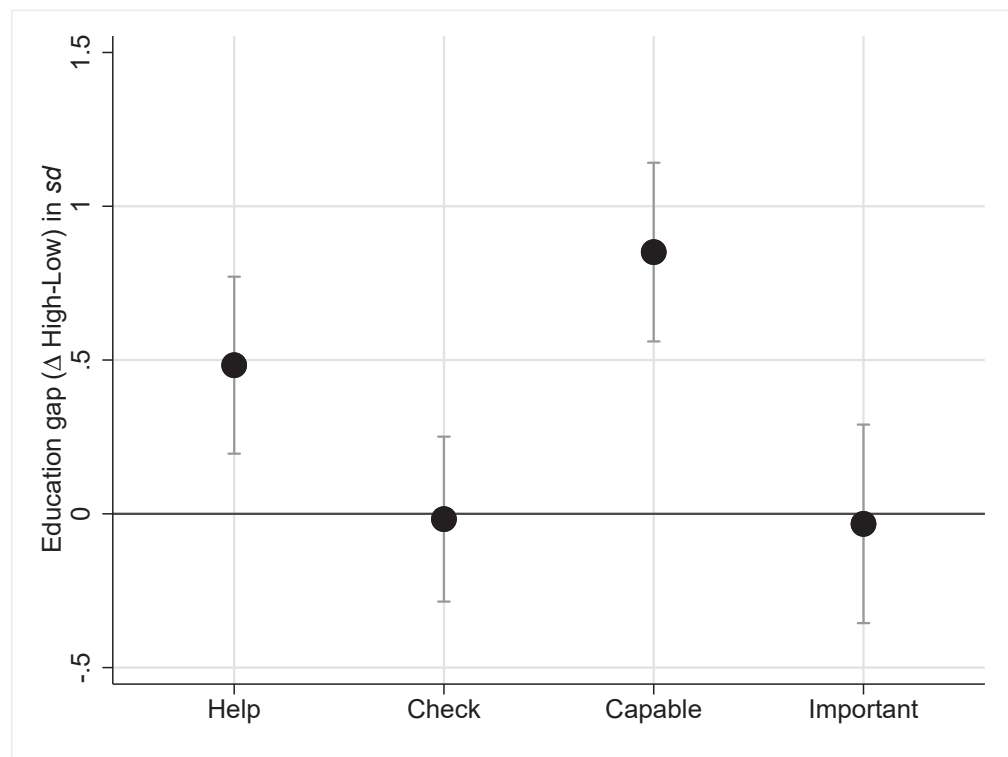

Note. - Predicted gaps based on a regression model, controlling for the age of the child, a binary indicator measuring whether the child worked from home, an indicator for school year, and a dummy for the school track the child is in. Whiskers depict $95 \%$ confidence intervals. Standard errors are clustered at parent and household level.

The largest gap, however, is in the extent to which parents feel capable to help their children: a gap of almost $.9 \mathrm{sd}$. This gap is visualized in Figure 10. It becomes clear that higher educated see themselves as much more capable to help their children. About $75 \%$ of the parents with an academic education feels themselves capable to help their children, compared to only $40 \%$ of the lower educated parents. However,Figure 9 also makes clear that all parents find it equally important that their children make their schoolwork. This indicates that there are large disparities in the possibilities that parents have to help their children during the school shutdown.

\subsubsection{Material resources}

Figure B2 shows the description of the material resources. Compared to primary education, children in secondary education have much more access to material resources. More than $90 \%$ of the parents reports that their children have their own room, a quiet place to study, and a laptop or tablet they can use for their schoolwork. This percentage is partly explained by the fact that $95 \%$ of the parents reports that a laptop or tablet is necessary to do the schoolwork at home. 
Figure 10: Capability to help (secondary education)

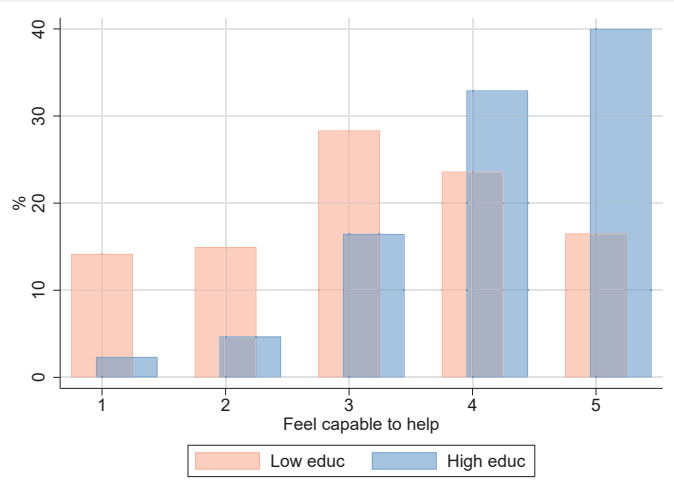

Figure 11: Material resources and poverty (secondary education)

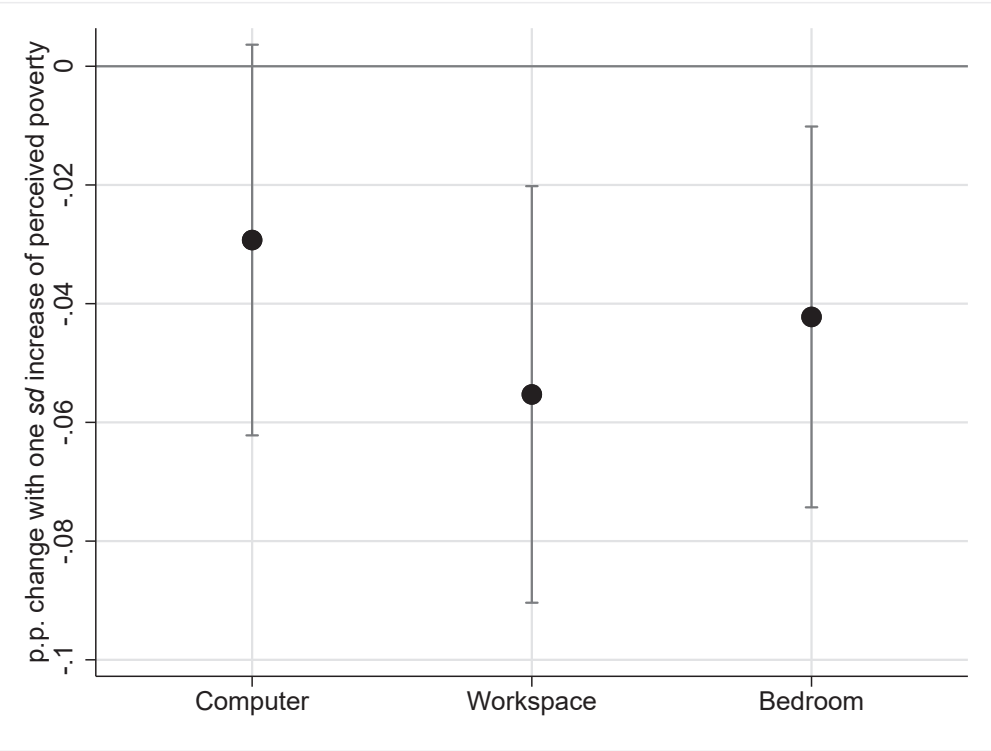

Note. - Predicted gaps based on a regression model, controlling for the age of the child, a binary indicator measuring whether the child worked from home, an indicator for school year, and a dummy for the school track the child is in. Whiskers depict 95\% confidence intervals. Standard errors are clustered at parent and household level.

Figure 11 shows the extent to which there are gaps between families with different income levels. Families that live in poverty are less likely to provide their children with a computer or laptop, although this effect does not reach statistical significance. The poverty gap in workspace and bedroom are significant and constitute 4 to 6 percentage points. I find that the lack of material resources that are necessary for doing the schoolwork at home is clustered in some households.

\subsection{Gender inequality}

A final interesting gap in secondary education is found between boys and girls. Figure 12 indicates that the school shutdown is likely to have different effects for 
boys than for girls. In secondary education, parents are more likely to help their daughters than their sons. Partly this is because they feel more capable to help their daughters than sons, with about a $.2 s d$ gap on the five-point scale. Partly this might also be explained by the fact that parents report that their daughters like doing their schoolwork more than their sons-a difference that already exists in primary education (not reported here).

Figure 12: Gender gap in schoolwork

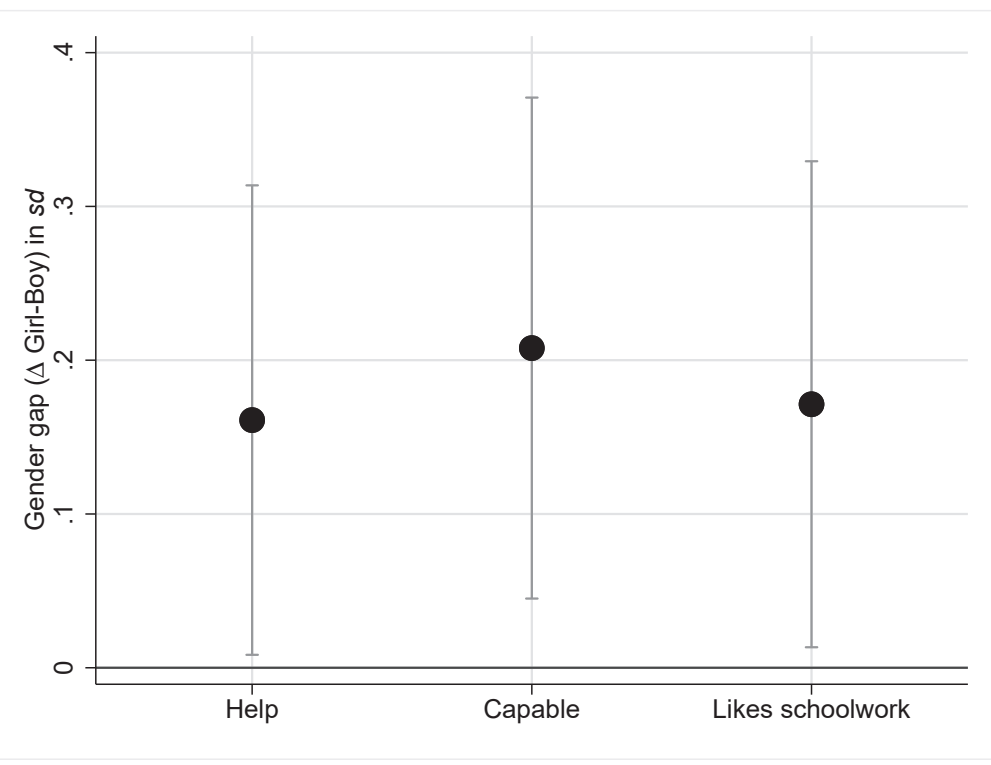

Note. - Predicted gaps based on a regression model, controlling for the age of the child, a binary indicator measuring whether the child worked from home, an indicator for school year, and a dummy for the school track the child is in. Whiskers depict $95 \%$ confidence intervals. Standard errors are clustered at parent and household level.

Similar to family background, be it parental education or poverty, educational inequalities between boys and girls are also likely to enlarge during the school shutdown. Girls receive more help, parents feel more capable helping them, and parents report that they like their schoolwork more.

\section{Conclusion}

The Covid-19 outbreak has led to school shutdowns around the world, thereby making parents primarily responsible for the learning of their children. In April data were collected on the homeschooling practices of parents in the Netherlands. A specific goal of this data collection was to map how parents from different socio-economic backgrounds provided different support with the schoolwork of their children. The initial results provide strong evidence that there are large gaps in how children have learned during the school shutdown.

In primary education, parents with a high educational background believe that their children need more support with their schooling and thus also provide 
more support. Strikingly, even in primary education there is a large gap in the extent to which parents feel themselves capable to support their children. The first results also indicate some differences with respect to material resources, and particularly families in poverty have more difficulties in providing resources that might improve learning from home. Differences in material resources are found for children in both primary and secondary education.

In secondary education there there is a very large gap in parental support between children with higher and lower educated parents. About $75 \%$ of the parents with academic education feel themselves capable to support their children with their schoolwork, compared to only $40 \%$ of the lower educated parents. Gender plays a role too: parents support their sons less, feel less capable of supporting them, and report that boys enjoy doing their schoolwork much less than girls. The school shutdown is thereby also likely to increase gender inequality in education.

School involvement tends to be higher for children who have lower educated parents. At the same time I find that schools offer children from the highest track (vwo) a much more structured educational programme including digital classes than children from the pre-vocational track (vmbo). This signals that the school shutdown also affects educational levels in secondary education differently.

The first results from this data collection provides strong indications that the school shutdown caused by the Covid-19 pandemic will increase existing inequalities in education. Children from disadvantaged families received much less support from their parents, which is likely to have impeded their learning during this period. 


\section{References}

Alexander, Karl L., Doris R. Entwisle, and Linda S. Olson. 2001. "Schools, Achievement, and Inequality: A Seasonal Perspective." Educational evaluation and policy analysis 23:171-191.

Alexander, Karl L., Doris R. Entwisle, and Linda Steffel Olson. 2007. "Lasting Consequences of the Summer Learning Gap." American sociological review 72:167-180.

Angus, Lawrence, Ilana Snyder, and Wendy Sutherland-Smith. 2004. "ICT and Educational (Dis) Advantage: Families, Computers and Contemporary Social and Educational Inequalities." British Journal of Sociology of Education 25:318.

Boonk, Lisa, Hieronymus JM Gijselaers, Henk Ritzen, and Saskia Brand-Gruwel. 2018. "A Review of the Relationship between Parental Involvement Indicators and Academic Achievement." Educational Research Review 24:10-30.

Bourdieu, P. 1973. "Cultural Reproduction and Social Reproduction." Knowledge, education and cultural change. London: Tavistock pp. 487-510.

Breen, Richard and Jan O. Jonsson. 2005. "Inequality of Opportunity in Comparative Perspective: Recent Research on Educational Attainment and Social Mobility." Annual Review of Sociology 31:223-243.

Calarco, Jessica McCrory. 2018. Negotiating Opportunities: How the Middle Class Secures Advantages in School. Oxford University Press.

Driessen, Geert, Frederik Smit, and Peter Sleegers. 2005. "Parental Involvement and Educational Achievement." British educational research journal 31:509532.

Inspectie van het Onderwijs. 2017. De Staat van Het Onderwijs 2015/2016. Utrecht: Inspectie van het Onderwijs.

Lareau, Annette. 2011. Unequal Childhoods: Class, Race, and Family Life. University of California Press.

Lee, Jung-Sook and Natasha K. Bowen. 2006. "Parent Involvement, Cultural Capital, and the Achievement Gap among Elementary School Children." American educational research journal 43:193-218. 


\section{A Questionnaire items (Dutch)}

v3:In hoeverre zijn de volgende uitspraken van toepassing op de situatie van Kind $X ?$

(a) Na de schoolsluiting heb ik van de basisschool informatie gekregen waardoor Kind $X$ thuis verder kon werken.

(b) De basisschool verzorgt digitale lessen voor Kind $X$.

(c) Kind $X$ heeft regelmatig contact met zijn/haar juf of meester.

(d) Er wordt duidelijk naar ouders gecommuniceerd wat er van mij verwacht wordt voor de thuisscholing van Kind $X$.

(e) De basisschool biedt een gestructureerd lesprogramma aan voor Kind $X$.

(f) Ik heb contact (gehad) met de juf en meester van Kind $X$ om het thuisonderwijs te bespreken.

(g) Het gemaakte huiswerk wordt door de juf of meester nagekeken.

(h) Om het schoolwerk thuis te kunnen doen is een computer of tablet nodig.

v4: Hoeveel tijd besteedt Kind $X$ op een doordeweekse dag gemiddeld aan zijn of haar schoolwerk?

v5: In hoeverre zijn de volgende uitspraken van toepassing op de scholing van Kind $X$ ?

(a) Ik help Kind $X$ bij zijn/haar schoolwerk.

(b) Ik controleer bij Kind $X$ of zijn/haar schoolwerk voor die dag is afgerond.

(c) Kind $X$ organiseert zijn of haar schoolwerk voor die dag zelf.

(d) Ik overhoor Kind $X$ over wat hij/zij geleerd heeft.

(e) Er zijn doordeweeks vaste tijden waarop Kind $X$ werkt aan school.

(f) Kind $X$ heeft veel hulp nodig bij zijn/haar schoolwerk.

(g) Ik voel me goed in staat om Kind $X$ te helpen met zijn/haar schoolwerk.

(h) Ik heb genoeg tijd om Kind $X$ te helpen met zijn/haar schoolwerk.

(i) Kind $X$ mag zelf weten hoeveel hij/zij die dag aan school werkt.

(j) Kind $X$ vindt het leuk om thuis aan school te werken.

(k) Ik kijk het schoolwerk van Kind $X$ na.

(l) Ik vind het belangrijk dat Kind $X$ zijn/haar schoolwerk goed bijhoudt.

(m) Kind $X$ kan thuis in stilte werken aan zijn/haar schoolwerk.

v6: In hoeverre zijn de volgende uitspraken van toepassing op Kind $X$ in het basisonderwijs ${ }^{5}$ ?

(a) Ik bied thuis digitale hulpmiddelen aan die ik zelf betaal (Squla, Rekentuin, Taalzee, enzovoorts) om Kind $X$ te ondersteunen bij het leren.

(b) Kind $X$ volgt in deze periode (online) bijles, buiten de lessen die door school verzorgd worden.

(c) Kind $X$ heeft een eigen computer of tablet om op te werken.

(d) Kind $X$ heeft thuis een eigen werkplek.

(e) Kind $X$ heeft een eigen slaapkamer.

\footnotetext{
${ }^{5}$ Questions were slightly adapted for children in secondary education
} 
v8: Kunt $\mathrm{u}$ aangeven in hoeverre de volgende uitspraken van toepassing zijn?

(a) Wij gaan als gezin ieder jaar meerdere keren op vakantie.

(b) Als mijn kind bij een (sport)club wil, dan is dat zonder meer mogelijk.

(c) Mijn kind geeft elk jaar een verjaardagsfeestje

(d) We hebben genoeg geld om leuke dingen te doen met het gezien.

v12: In hoeverre zijn de volgende uitspraken van toepassing op uw thuissituatie op dit moment?

(a) Gezinsleden vinden het leuk om vrije tijd samen door te brengen.

(b) Er zijn spanningen als iedereen thuis is.

(c) Als we samen zijn, is de sfeer ongemakkelijk.

(d) We hebben ruzie over kleine dingen.

(e) Er is bij ons thuis een vaste dagelijkse routine.

(f) Het is vaak onrustig bij ons thuis. 


\section{B Supplementary figures}

Figure B1: School involvement

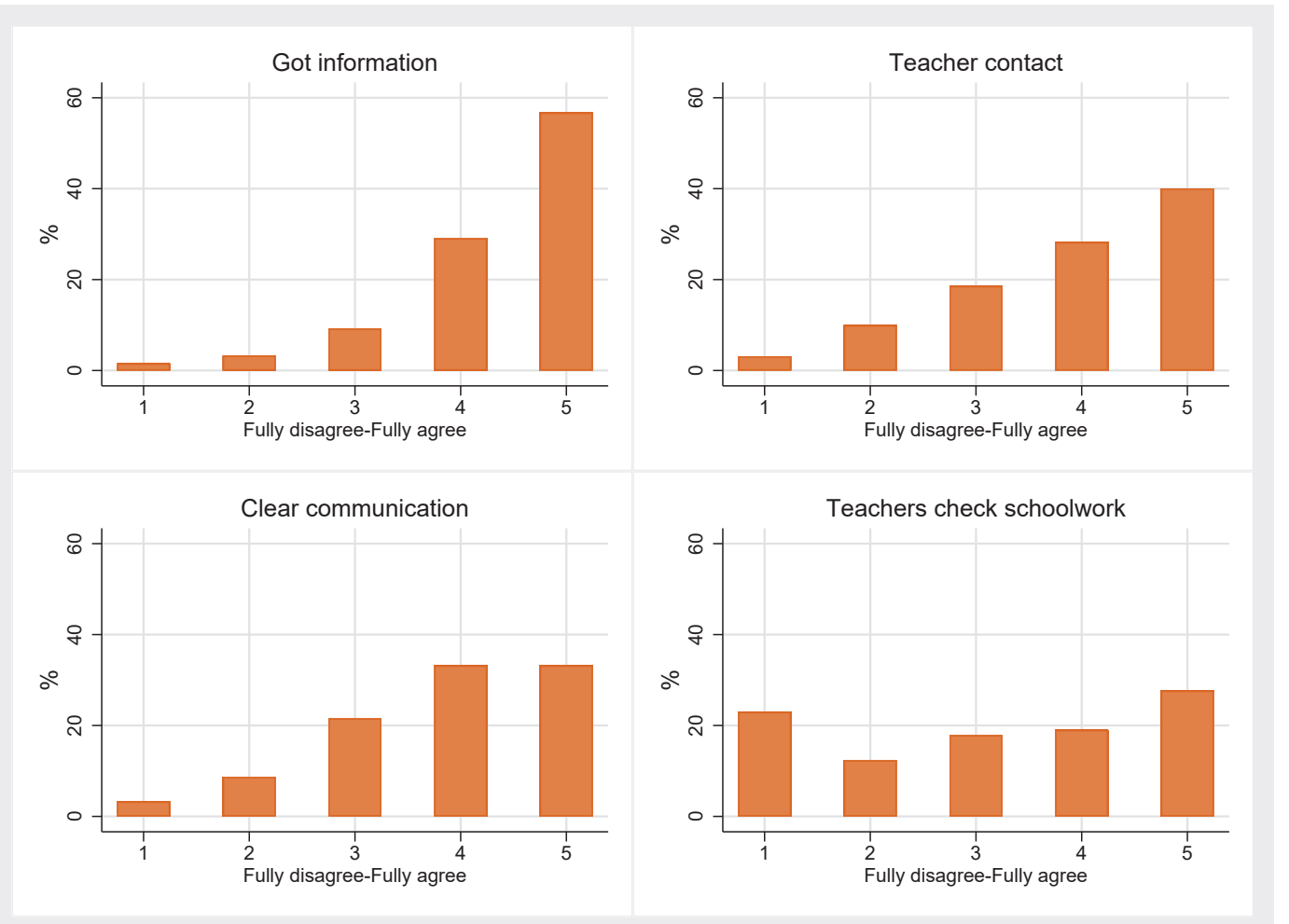

Note. - For the full questions see the Appendix. 
Figure B2: Material resources

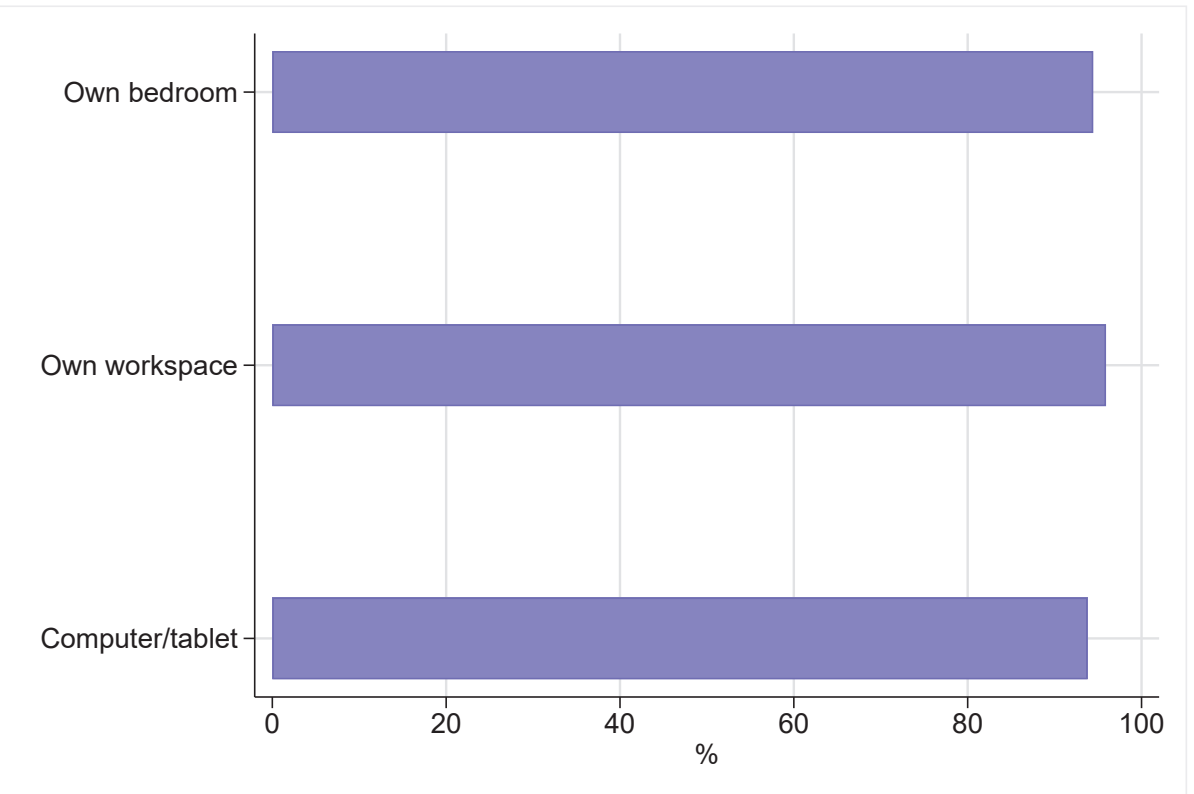

Note. - For the full questions see the Appendix. 